Research Article

\title{
Housing Sources of Second-Tier Urban Residents Based on Multivariate Correspondence
}

\author{
Feng Zhang $\mathbb{D D}^{1}$ and Anlin $\mathbf{L i}^{2}$ \\ ${ }^{1}$ School of Management Engineering, Shandong Jianzhu University, Jinan 250101, China \\ ${ }^{2}$ School of Management, University of Shanghai for Science and Technology, Shanghai 200093, China \\ Correspondence should be addressed to Feng Zhang; sd_zhangfeng@sdjzu.edu.cn
}

Received 16 August 2019; Revised 8 December 2019; Accepted 6 January 2020; Published 17 February 2020

Academic Editor: Abdul Aziz bin Abdul Samad

Copyright (c) 2020 Feng Zhang and Anlin Li. This is an open access article distributed under the Creative Commons Attribution License, which permits unrestricted use, distribution, and reproduction in any medium, provided the original work is properly cited.

\begin{abstract}
To explore the relationship between different housing sources and individual attributes in second-tier cities, finding the key point of contradiction between supply and demand in the real estate market is important. Multivariate correspondence analysis (MCA) is a powerful method to solve the complex problem of the relationship between classified variables. Also known as corresponding analysis, it is a multivariate statistical analysis method that aims to describe the relationship between two classification variables in a corresponding table in a low-dimensional space. MCA has unique advantages when dealing with categorical variable data. It combines the advantages of factor analysis and multidimensional scaling. On the basis of combining and analysing the existing literature, this paper makes an analysis of the data obtained from a housing questionnaire survey collected in Jinan, Shandong Province, in 2017. The research results show that the housing sources of second-tier urban residents are closely related to age, annual family income, marriage, education level, and individual characteristics of the permanent family population but not to gender.
\end{abstract}

\section{Introduction}

In the past decade, the Chinese real estate market has developed rapidly, and the development of the second-tier city has become a significant part of this market [1-3]. As a group, the second-tier city real estate market has a crucial effect on the development of the whole economic market because it has a massive population size, great virtue of economic strength, and control of the ground, which can become the nucleus from which to lead the evolution of the real estate market system [4-6]. Thus, it is more than significant for us to correctly understand the strategic position, development trends, and development phases of the secondtier city's real estate market within the entire Chinese market [7-9]. The second-tier city is a variational concept and will thus be different throughout its different phases [10-12]. This article defines a second-tier city as a city comprised of a large scale within its province, excluding the first-tier cities (e.g., Beijing, Shanghai, Guangzhou, and Shenzhen).
This research's object is Jinan, which is the capital city of Shandong Province and the province's centre of the politics, economy, culture, financing, transportation, and education. It also has many springs in the downtown area, such as "72 MingQuan" and the "Baotu Spring," which is called the first spring in the world and is the reason why Jinan is called the City of the Spring. Jinan is the national historical and cultural city of China and contains mountains, lakes, and numerous lotus plants and willows. In 2017, the statistics of the Newspaper of National Economy and Society Development revealed that, in Jinan, the real estate market investment has increased slowly. This investment has reached 123.26 billion yuan, increasing by $5.9 \%$, and among these investments, the residential building investments have reached 82.28 billion yuan, increasing by $2.1 \%$. The total building construction consists of 80.068 million square metres, increasing by $1.2 \%$; among this construction, the total residential construction consists of 53.289 million square metres, increasing by $1.6 \%$. The completed buildings 
consist of 6.313 million square metres, among which the completed residential buildings consist of 4.911 million square metres. The control and adjustment of the real estate market have evident effectiveness [13-15]. The total portion of the sold commodity housing is 121.53 million square metres, decreasing by $14.7 \%$; among this total, the portion of the sold residential housing is 97.37 million square metres, decreasing by $20.9 \%$. The total sales of commodity housing have reached 117.26 billion yuan, decreasing by $0.2 \%$; among these sales, the total sales of residential housing have reached 94.63 billion yuan, decreasing by $8.6 \%$. On the one hand, the increase in sales in the area reflects the continued rise in inventory under dull market transactions and the continued game between real estate companies and home buyers. On the other hand, many studies have paid more attention to first-tier cities rather than second-tier cities. This article will mainly pay attention to the connection between the housing source and the citizen in Jinan, Shandong Province, and determine its mechanisms. That is why we chose Jinan as the research object.

\section{Literature}

The real estate market in China has had explosive development since the housing system reform of 1998 [15-17]. People have various ways of obtaining a house, such as selfbuilt housing, purchasing commodity housing, purchasing affordable housing, purchasing public-owned housing, renting public-owned housing, and renting commodity housing, instead of depending on the government's welfare housing [18-20]. Many domestic and overseas scholars have researched the connection between housing sources and individual attributes and have found many consistent conclusions. In 1980, Lhlanfeldt posited that, in the life cycle stage, consumer individual attributes such as actual normal income, race, and occupation were the basic factors to be considered in the decision to buy a house, and older age, marriage, and large family size all contributed to home ownership [21]. In terms of family economic status, in 1977, Michelson studied how families choose houses and the search process for residential location. He discovered that financial status was the main factor affecting family migration, while education level affected family life style [21]. The above two factors were highly correlated with residential location selection. Jun used correspondence analysis and optimal scales to conduct empirical research and analysis on consumer behaviour in the housing market and concluded that monthly income is closely related to housing [22]. Fen used a multivariate statistical method to analyse the housing consumption of urban residents in Tianjin [23]. The research results suggested that the annual household income is the main factor affecting the purchase standard, and consumers with an annual income of 80,000 to 100,000 yuan tend to buy 90 to 120 square metres of housing. In 2010, Liu et al. analysed the housing type differentiation transformation under the background of China's urban residents and its influencing factors. This research found that since the reform and opening up, China's urban housing ownership rate has increased significantly and that variables such as family life cycle, family income, household register, work-unit properties, and profession significantly influence the housing choice and reflect the market and the system of the dual effects of housing resources allocation [24]. Qian conducted relevant research on the demand preference of housing types and performed corresponding analysis and multidimensional preference analysis results of the secondtier city of Baoding with SPSS software [25].

This research found that disposable income, the market housing ratio, the commercial housing ratio, the purchase of commercial housing (which has its own ratio), and self-built housing [26] are not significant, except that public housing has its own correlation coefficient at the $p<0.01$ level. Housing property rights are related not only to income but also to housing prices [27]. Generally, in the market economy, people will have a stronger housing affordability when their income is higher [28, 29]. The means of housing acquisition, housing differences, and the results of housing stratification often interact with each other, among which occupation, education, income, and family life cycle are important influencing factors. Marriage and birth status are important factors affecting the housing source of urban youth [30, 31]. Marriage and birth as important life events significantly improve the possibility of young people purchasing a house $[32,33]$. Foreign scholars have carried out research based on a variety of research perspectives and methods of residential housing sources in the market; for example, Jayasekare posits that houses with desired aesthetic views have a price premium over similar houses without such views [34]. Currently, some researchers are studying the connection between environmental protection and housing prices. Due to the prevailing environmental protection concept, green building and green construction will increase the cost of construction companies and affect the price [35]. According to statistics, approximately $30-40 \%$ of total raw material and final use are consumed by the construction industry, which proves that material makes a large proportion of this industry [21, 22]. Meanwhile, green construction, which was the concept of sustainable development, also appeared in the construction industry and, according to Jun [34], aims to protect nature by reducing the building impacts on the environment and will increase the price of housing. Furthermore, many green constructions have been stopped because of their additional cost and extra time [36], and this difficulty has become the main factor obstructing the development of technology and influencing the price.

However, by not using multiple correspondence analysis to determine the individual attribute characteristics and the source of urban housing, the study of the source of housing is relatively small; therefore, careful study is needed to determine the source of urban housing and its closely related attributes, as well as to explore the housing source and the link between residents' property and regularity.

Correspondence analysis is a powerful tool for the analysis of categorical variables [37]. It is a visual data analysis method that can display groups of data without any connection through visually acceptable positioning maps $[38,39]$. This method uses the idea of dimensionality 
reduction to simplify the data structure $[38,40]$. It is simple and intuitive and is widely used in the fields of market segmentation, product positioning, geological research, and computer engineering $[39,41]$. This paper applies multivariate correspondence analysis (described as the correspondence between three or more variables) to the analysis and evaluation of individual attributes and housing sources. Theoretically, this use broadens the research field of correspondence analysis. From the perspective of application, it provides a theoretical basis for promoting the stable development of the real estate market. Based on this, this study starts from housing sources in second-tier cities and applies the method of multiple correspondence analysis to classify housing sources from different channels, thereby providing theoretical support for the classified management of national real estate management departments. Thus, the current study provides a theoretical basis and path reference for the government's macro control.

\section{The Hypothesis}

Based on existing theories and the current situation of China's housing market, this paper proposes a relationship between the individual attributes and housing sources of urban residents. To facilitate questionnaire research, the hypotheses of the corresponding variables, including gender, age, education level, marriage, occupation, family resident population, family annual income, and housing source, are preliminarily determined on the basis of summarizing and absorbing existing research results. Among these variables, the seven variables of gender, age, education level, marriage, occupational family, permanent resident population, and family income can be described as individual attribute characteristics. Housing sources can be divided into the following five types: renting a house, living with parents, purchasing commodity housing, purchasing affordable housing, and other types of housing. This paper mainly studies the relationship between these seven individual attributes and five housing sources. This article proposes the following seven hypotheses: (1) men are more likely than women to purchase houses; (2) older people are more likely than young adults to purchase houses; (3) the more educated people are, the more likely they are to buy a house; (4) married people are more likely to buy a house than unmarried people; (5) people with stable jobs are more likely to buy a house; (6) the larger the number of family residents, the more likely the family will buy a house; and (7) the higher the annual household income, the more tendency the family has to buy a house. The classification of eight variables (see Table 1) was conducted, and the multivariate correspondence analysis of these eight variables was conducted to explore the characteristics and regularities of urban residents' housing sources in Jinan, which is a second-tier city in Shandong Province.

3.1. Data Source and Processing. Before the formal release of a questionnaire on a large scale and to test its initial consistency and validity, a questionnaire needs to be pretested on a small scale. By utilizing the data from the pretest, by examining the reliability and validity of the questionnaire to better formulate the measurement items and by communicating with the respondents to better understand their questions about the structure, methods, and so on of this questionnaire, the questionnaire was more effective in obtaining the required data, and the quality of the questionnaire was improved. For subsequent empirical analysis, the results provide strong results.

In the pretest of this questionnaire, paper and e-mail questionnaires were mainly distributed to randomly distributed individuals in each residential district. Specifically, after a housing questionnaire of urban residents was conducted following interviews with real estate experts, a questionnaire survey of urban residents in Jinan city, Shandong Province, was conducted using a household survey. A total of 300 copies of the pretest questionnaire were distributed, and 298 copies were returned, for a recovery rate of $99 \%$. The pretest questionnaire was adjusted to a formal questionnaire by consulting experts and related professionals. To facilitate communication, a special housing questionnaire survey focus group was established, and the members of the group received professional training on the questionnaire survey. Then, a large-scale face-to-face questionnaire survey was conducted in January 2017. The questionnaires were archived and numbered, and 1032 questionnaires were collected in the end. Through manual screening, the questionnaires containing the same consecutive answers for 10 or more questions and those with missing data were removed from the sample. A total of 989 valid questionnaires were obtained, for an effective rate of $96 \%$.

\subsection{Current Characteristics of the Housing Consumption of} Urban Residents. From the 989 observations in the sample, the sample characteristics can be seen in Table 2. In terms of gender, there are 523 males, accounting for $52.9 \%$, and 466 females, accounting for $47.1 \%$. In terms of age, 625 people are under 35 years old, accounting for $63.2 \%$; 285 people are 35 to 50 years old, accounting for $28.8 \%$; and 79 people are over 50 years old, accounting for $8 \%$. In terms of education level, 470 people are without a bachelor's degree, accounting for $47.5 \%$; 445 people have bachelor's degree, accounting for $45 \%$; and 74 respondents have a master's degree or above, accounting for $7.5 \%$. In terms of work units, government institutions accounted for $18.2 \%$ of the respondents, state-owned enterprises accounted for $21.6 \%$ of the respondents, joint venture or foreign-funded enterprises accounted for $5.9 \%$ of the respondents, privately owned or private enterprises accounted for $29.1 \%$ of the respondents, and other units accounted for $25.2 \%$ of the respondents. In terms of household income, $58.9 \%$ of the respondents had a total household income below 100,000 yuan, $37.9 \%$ of the respondents had a total household income between 100,000 yuan and 350,000 yuan, and 3.1\% of the respondents had a total household income above 350,000 yuan. In terms of living situation, 118 respondents rented a house, accounting for $11.9 \%$; 299 respondents lived with their parents, accounting for $30.2 \%$; 372 respondents had purchased commercial housing, accounting for 37.6\%; 97 
Table 1: Variable classification table.

\begin{tabular}{|c|c|c|c|c|c|c|c|c|}
\hline Variable & Gender & Age & $\begin{array}{l}\text { Degree of } \\
\text { education }\end{array}$ & Marriage & Occupation & $\begin{array}{l}\text { Permanent } \\
\text { resident } \\
\text { population }\end{array}$ & $\begin{array}{c}\text { Annual } \\
\text { household } \\
\text { income (yuan) }\end{array}$ & $\begin{array}{l}\text { Housing } \\
\text { source }\end{array}$ \\
\hline 1 & Man & $\begin{array}{c}\text { Under } 25 \\
\text { years }\end{array}$ & $\begin{array}{l}\text { Below high } \\
\text { school }\end{array}$ & Single & $\begin{array}{l}\text { Government } \\
\text { institutions }\end{array}$ & One person & $\begin{array}{l}\text { Under } 50 \\
\text { thousand }\end{array}$ & Renting a house \\
\hline 2 & Woman & $\begin{array}{c}25 \text { years to } \\
35 \text { years }\end{array}$ & $\begin{array}{l}\text { High school/ } \\
\text { junior college }\end{array}$ & Married & $\begin{array}{c}\text { State-owned } \\
\text { enterprise }\end{array}$ & Two persons & $\begin{array}{l}50 \text { thousand to } \\
100 \text { thousand }\end{array}$ & Lives with parents \\
\hline 3 & & $\begin{array}{l}35 \text { years to } \\
50 \text { years }\end{array}$ & Undergraduate & Others & $\begin{array}{c}\text { Joint venture/ } \\
\text { foreign- } \\
\text { owned enterprise }\end{array}$ & Three persons & $\begin{array}{c}100 \text { thousand } \\
\text { to } 180 \\
\text { thousand }\end{array}$ & $\begin{array}{l}\text { Commercial } \\
\text { housing }\end{array}$ \\
\hline 4 & & $\begin{array}{c}\text { Age more } \\
\text { than } 50 \\
\text { years }\end{array}$ & Master's or above & & $\begin{array}{c}\text { Privately } \\
\text { operated/private } \\
\text { enterprise }\end{array}$ & Four persons & $\begin{array}{c}180 \text { thousand } \\
\text { to } 250 \\
\text { thousand }\end{array}$ & $\begin{array}{l}\text { Economically } \\
\text { affordable housing }\end{array}$ \\
\hline 5 & & & & & Others & $\begin{array}{c}\text { More than five } \\
\text { persons }\end{array}$ & $\begin{array}{c}250 \text { to } 350 \\
\text { thousand }\end{array}$ & Others \\
\hline 6 & & & & & & & $\begin{array}{l}\text { Over } 350 \\
\text { thousand }\end{array}$ & \\
\hline
\end{tabular}

TABLE 2: Survey sample survey.

\begin{tabular}{|c|c|c|c|}
\hline Item & Category & Number of people & Percentage (\%) \\
\hline \multirow{4}{*}{ Degree of education } & Below high school & 94 & 9.5 \\
\hline & High school/junior college & 376 & 38.0 \\
\hline & Undergraduate & 445 & 45.0 \\
\hline & Master's or above & 74 & 7.5 \\
\hline \multirow{3}{*}{ Marriage } & Single & 368 & 37.2 \\
\hline & Married & 602 & 60.9 \\
\hline & Others & 19 & 1.9 \\
\hline \multirow{5}{*}{ Occupation } & Government institutions & 180 & 18.2 \\
\hline & State-owned enterprise & 214 & 21.6 \\
\hline & Joint venture/foreign-owned enterprise & 58 & 5.9 \\
\hline & Privately operated/private enterprise & 288 & 29.1 \\
\hline & Others & 249 & 25.2 \\
\hline \multirow{5}{*}{ Permanent resident population } & One person & 33 & 3.3 \\
\hline & Two persons & 130 & 13.1 \\
\hline & Three persons & 533 & 53.9 \\
\hline & Four persons & 189 & 19.1 \\
\hline & More than five persons & 104 & 10.5 \\
\hline \multirow{2}{*}{ Gender } & Man & 523 & 52.9 \\
\hline & Woman & 466 & 47.1 \\
\hline \multirow{4}{*}{ Age } & Under 25 years & 256 & 25.9 \\
\hline & 25 years to 35 years & 369 & 37.3 \\
\hline & 35 years to 50 years & 285 & 28.8 \\
\hline & More than 50 years & 79 & 8.0 \\
\hline \multirow{6}{*}{ Annual household income } & Under 50 thousand yuan & 203 & 20.5 \\
\hline & 50 thousand to 100 thousand yuan & 380 & 38.4 \\
\hline & 100 thousand to 180 thousand yuan & 266 & 26.9 \\
\hline & 180 thousand to 250 thousand yuan & 76 & 7.7 \\
\hline & 250 thousand to 350 thousand yuan & 33 & 3.3 \\
\hline & Over 350 thousand yuan & 31 & 3.1 \\
\hline \multirow{5}{*}{ Housing source } & Renting a house & 118 & 11.9 \\
\hline & Lives with parents & 299 & 30.2 \\
\hline & Commercial housing & 372 & 37.6 \\
\hline & Economically affordable housing & 97 & 9.8 \\
\hline & Others & 103 & 10.4 \\
\hline
\end{tabular}


respondents had purchased affordable housing, accounting for $9.8 \%$; and 103 respondents listed their living situation as other, accounting for $10.4 \%$. Overall, respondents with a bachelor's degree or above and young people whose family income is less than 100,000 yuan are the majority in the sample.

\subsection{Multiple Correspondence Analysis of Housing Sources of} Urban Residents. In multivariate correspondence analysis, the highest number of dimensions available depends on the number of categories in the variables. The calculation formula of the highest number of dimensions available is as follows:

$$
\begin{aligned}
& \text { The highest number of dimensions available } \\
& =\text { The number of categories in the variable } \\
& \text { - The number of variables. }
\end{aligned}
$$

If the number of samples is lower than this difference, the maximum dimension is the number of samples. In this study, the maximum number of dimensions that can be selected is 26 :

$$
2+4 \times 2+3+5 \times 3+6-8=26 .
$$

The characteristic root of each dimension represents the explanatory degree of each variable of the dimension. The larger the value is, the better the differentiation degree of each variable on the dimension is, and the maximum value is 1. However, due to the use of optimal scale transformation, the extraction of characteristic roots of each dimension is carried out independently, so it cannot represent the total interpretation degree of the model; that is to say, it is impossible to know the total interpretation degree of the model, which is the shortcoming of multivariate correspondence analysis based on optimal scale transformation.

The output results from SPSS include the discriminating measures table and the discriminating measurement graph of the multivariate correspondence analysis. The graph shows the discriminating degree of each variable in two dimensions in the form of scatter coordinates. The size of the discriminating measure is between 0 and 1 , and the higher the value, the higher the degree of differentiation. By analysing the discrimination measures of the multivariate correspondence analysis (Table 3) and the discrimination measurement graph (Figure 1), it can be seen that age has a high degree of discrimination in both dimensions, with an average value of 0.5065 , which is the highest discrimination degree among all variables. Age is closely related to the housing source. The housing sources are also highly differentiated. Some of the other variables have a good degree of differentiation in the first dimension; for example, marriage has a good degree of differentiation in the first dimension; however, some variables have a better degree of differentiation in the second dimension, such as education and occupation. Family annual income and family resident population are well distinguished in the second dimension. However, gender has a poor and very small degree of differentiation in both dimensions. The smallest mean value of all the variables is 0.015 . This is consistent with the actual
TABLE 3: Distinguishing measures for multivariate correspondence analysis.

\begin{tabular}{lccc}
\hline & \multicolumn{2}{c}{ Dimension } & \multirow{2}{*}{ Mean } \\
& 1 & 0.237 & \\
\hline Gender & 0.009 & 0.012 & 0.0105 \\
Age & 0.776 & 0.237 & 0.5065 \\
Degree of education & 0.093 & 0.454 & 0.2735 \\
Marriage & 0.781 & 0.047 & 0.414 \\
Occupation & 0.249 & 0.229 & 0.239 \\
Permanent resident population & 0.043 & 0.151 & 0.097 \\
Annual household income & 0.088 & 0.192 & 0.14 \\
Housing source & 0.544 & 0.337 & 0.4405 \\
\hline
\end{tabular}

situation, in which the type of house one lives in is closely related to their family situation and the annual income of their family, but not much related to their gender. The differentiation degree of the family permanent resident population is also very small. The mean value of the differentiation degree in the first and second dimensions is 0.097 , which indicates that the family permanent resident population is not closely related to the source of housing.

In the multivariate correspondence analysis diagram (see Figure 2), different categories of the same variables that fall from the point of origin in the same direction and in the same area of the graph have similar properties. Thus, classes of different variables that fall from the point of origin near the same orientation and in the same region of the graph may be related. According to the principle of multivariate correspondence analysis, the differentiation degree of the same variable is first investigated. This process entails examining whether the row variables and column variables are clearly separated by category. These differences can be examined separately in each dimension. If different categories of the same variable are close together in a certain direction, it means that these categories are not very different within this dimension. Therefore, it can be seen from the figure above that the two variables of family annual income and age are far from each other, which indicates that family annual income and age are closely related to housing source, and the categories of occupations are close together in the graph, indicating that there is little difference between occupations. Generally, the classification points of different variables in roughly the same region are related to each other, as they fall from the same orientation point starting from the graph origin $(0,0)$. Thus, the closer the scattered points are, the more obvious the correlation tendency is. Based on this explanation, it can be seen from the chart that there is a close relationship between an annual income of the family below 50,000 , an age of under 25 , and renting or living with one's parents. There is also a close relationship between an age from 35 to 50, an annual family income of 250,000 to 350,000 , and a permanent family population of more than 5 . Those who work in state-owned enterprises or government institutions have a master's degree or above, the annual income of their families is between 180,000 yuan and 250,000 yuan, and they have a close connection with purchasing a commodity housing. There is also a close correlation between a high school education and people over 50 


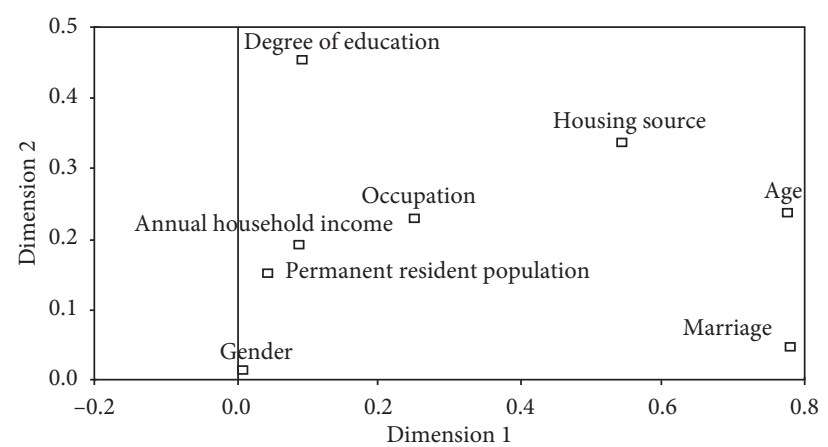

FIGURE 1: Distinguishing measure map of multivariate correspondence analysis.

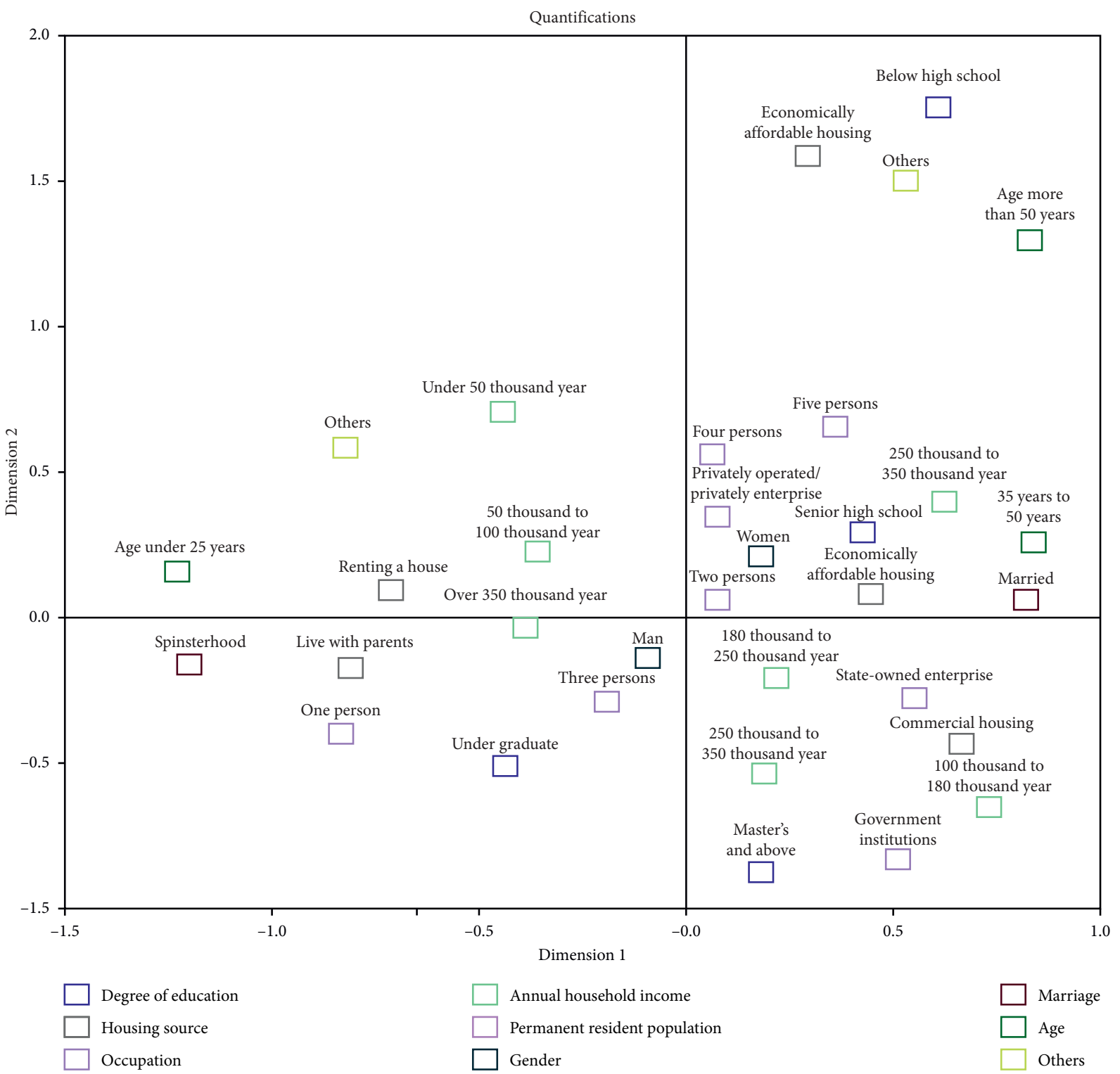

FIgURE 2: Quantitative scatter plot of multivariate correspondence analysis.

years old, which shows that the education of people over 50 years old is generally lower; in addition, more people over 50 years old report having welfare housing.
The object scoring diagram is an individual scatter diagram (see Figure 3), which is used to display the distribution of all observations in the corresponding 


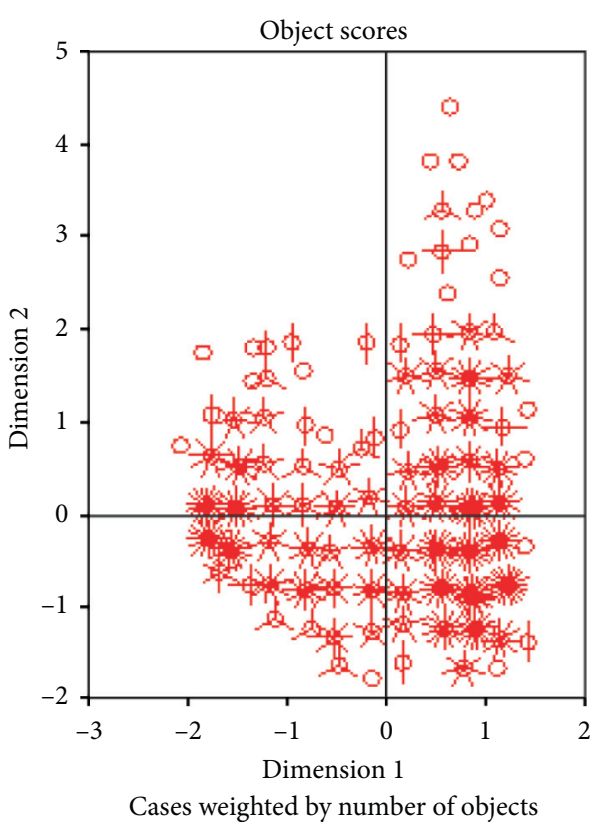

FIGURE 3: Object scoring diagram of multivariate correspondence analysis.

interpretation space, and this graph can be used to assist in macro control. In this study, the observation distribution is relatively dense, which has significant research significance.

\section{Conclusion}

In this article, multiple correspondence analysis is adopted to analyse the identity and background characteristics of residents in second-tier cities and obtain numerous multiple corresponding analysis diagrams. Based on practical research experience, this paper explores the characteristics of the background identity and housing sources of residents in Jinan; at the same time, multivariate statistical analysis has the advantages of visualization. Meanwhile, the analytic method calculates the singular value and characteristic root in the process of analysis, quantifies the degree of interpretation of the total amount of information, and improves the scientificity of the results. This article uses a category or character variable in the process of analysing it, which expands the application field and scope of data analysis. The conclusions are as follows.

Gender showed a lower degree of discrimination in the multivariate correspondence analysis. Gender is not a key factor affecting the source of housing, and both men and women need housing in cities. Therefore, the relationship between gender and housing source is not very close, which is in part contrary to the ancient custom that men should provide housing for marriage.

Age was highly differentiated and closely correlated with the source of housing, showing the highest correlation. People aged between 35 and 50 are likely to buy affordable housing, which is closely related to the real estate marketization of 1998, as employers that have worked since 1998 no longer offer any welfare housing. At present, in terms of housing sources, people over the age of 50 basically have more than two houses, i.e., one welfare house and one commercial house or other type of house; in addition, most people under the age of 25 either live with their parents or rent a house.

Education is highly differentiated, and the analysis results suggest that most people over the age of 50 have high school education, while most people aged between 25 and 35 have a bachelor's degree or higher education. This further indicates the popularization of education for all and the improvement of academic qualifications. There is little correlation between a bachelor's degree and housing source, as most of the respondents have a high degree and a high income level and buy commercial housing.

Marriage shows a high degree of differentiation in the multivariate correspondence analysis. Most unmarried people tend to live with their parents and then get married or other situations closely related to the purchase of housing. This is also consistent with Chinese customs, as most people tend to buy houses after they get married and have a family.

Occupation showed a high degree of differentiation in the multivariate correspondence analysis. The results show that the annual income of families in which the respondent works in private enterprises or private enterprises is between either 50,000 and 100,000 yuan or 250,000 and 350,000 yuan, which indicates that the income of private enterprises or private enterprises varies greatly. The annual income of families in which the respondent works in state-owned or state-owned enterprises is mostly 180,000 to 250,000 yuan, whereas the annual income of families in which the respondent works in government institutions is mostly 100,000 to 180,000 yuan. Therefore, it can be seen that one's occupation is closely related to the annual income of their family.

The family permanent resident population shows a low degree of differentiation in the multivariate correspondence analysis. When the number of permanent family members is 1, individuals most often live with their parents. Those with more than 3 permanent family members are closely related to the purchase of affordable housing or commercial housing. It can be seen that after the increase of family members, most people choose to buy housing instead of renting a house.

The annual household income shows a certain degree of differentiation in the multivariate correspondence analysis, but it is not the highest. However, there is a close correlation between family annual income and the purchase of commercial housing and affordable housing, which is consistent with the actual situation. Families with high annual income will naturally choose to buy a house rather than rent a house, which is closely related to people's ideology and concept of consumption concept. The analysis also shows that low household income is closely related to renting or living with one's parents.

\section{Data Availability}

The data used to support the findings of this study are available from the corresponding author upon request.

\section{Conflicts of Interest}

The authors declare that there are no conflicts of interest regarding the publication of this paper. 


\section{Acknowledgments}

The study is supported by the National Natural Science Foundation for Young Scientists of China, "Simulation Research on Housing Consumption Affordability and Regulation Policy of Income Class” (71403150).

\section{References}

[1] C. Yong Qiang and S. Tien, "Inflation hedging characteristics of the Chinese real estate market," Journal of Real Estate Portfolio Management, vol. 10, no. 2, pp. 145-154, 2004.

[2] E. Glaeser, W. Huang, Y. Ma, and A. Shleifer, "A real estate boom with Chinese characteristics," Journal of Economic Perspectives, vol. 31, no. 1, pp. 93-116, 2017.

[3] A. Walker and L. Hin, "Land use rights reform and the real estate market in China," Journal of Real Estate Literature, vol. 2, no. 2, pp. 199-211, 1994.

[4] Y. Zhao and S. C. Bourassa, "China's urban housing reform: recent achievements and new inequities," Housing Studies, vol. 18, no. 5, pp. 721-744, 2003.

[5] H. W. Wang and K. Wang, "What is unique about Chinese real estate markets?" Journal of Real Estate Research, vol. 34, no. 3, pp. 275-289, 2012.

[6] X. E. Xu and T. Chen, "The effect of monetary policy on real estate price growth in China," Pacific-Basin Finance Journal, vol. 20, no. 1, pp. 62-77, 2012.

[7] K. Y. Li, Y. Qin, and J. Wu, Housing Affordability in Urban China: A Comprehensive Overview, Springer, Berlin, Germany, 2018.

[8] S. Zheng, J. Cao, M. E. Kahn, and C. Sun, "Real estate valuation and cross-boundary air pollution externalities: evidence from Chinese cities," The Journal of Real Estate Finance and Economics, vol. 48, no. 3, pp. 398-414, 2014.

[9] G. Zhang and H.-G. Fung, "On the imbalance between the real estate market and the stock markets in China," The Chinese Economy, vol. 39, no. 2, pp. 26-39, 2006.

[10] G. K. M. Wong and L. Yu, "Consumers' perception of store image of joint venture shopping centres: first-tier versus second-tier cities in China," Journal of Retailing and Consumer Services, vol. 10, no. 2, pp. 61-70, 2003.

[11] M. Al-Hader, A. Rodzi, A. R. Sharif, and N. Ahmad, "SOA of Smart City Geospatial Management," in Proceedings of the 2009 Third UKSim European Symposium on Computer Modeling and Simulation, pp. 6-10, IEEE, Athens, Greece, November 2009.

[12] F. Guo and Y. S. Huang, "Does "hot money" drive China's real estate and stock markets?" International Review of Economics \& Finance, vol. 19, no. 3, pp. 452-466, 2010.

[13] X.-R. Wang, E. C.-M. Hui, and J.-X. Sun, "Population migration, urbanization and housing prices: evidence from the cities in China," Habitat International, vol. 66, pp. 49-56, 2017.

[14] C. H. Liu, D. J. Hartzell, W. Greig, and T. V. Grissom, "The integration of the real estate market and the stock market: some preliminary evidence," The Journal of Real Estate Finance and Economics, vol. 3, no. 3, pp. 261-282, 1990.

[15] H. Li, V. Li, M. Skitmore, J. K. W. Wong, and E. W. L. Cheng, "Competitiveness factors: a study of the real estate market in China," Construction Management and Economics, vol. 27, no. 6, pp. 567-579, 2009.

[16] J. Cao, B. H. Huang, and R. N. Lai, "On the effectiveness of housing purchase restriction policy in China: a difference in difference approach," SSRN Electronic Journal, 2005.
[17] S. S. Han, "Real estate development in China: a regional perspective," Journal of Real Estate Literature, vol. 6, no. 2, pp. 121-133, 1998.

[18] F. Wu, "Sociospatial differentiation in urban China: evidence from shanghai's real estate markets," Environment and Planning A: Economy and Space, vol. 34, no. 9, pp. 1591-1615, 2002.

[19] L. Yun Fang and G. Tiemei, "Empirical analysis on real estate price fluctuation in different provinces of China," Economic Research Journal, vol. 8, pp. 133-142, 2007.

[20] X. E. Xu and T. Chen, "The effect of monetary policy on real estate price growth in China," Pacific-Basin Finance Journal, vol. 20, no. 1, pp. 62-77, 2012.

[21] W. M. Michelson, Environmental Choice, Human Behavior, and Residential Satisfaction, Oxford University Press, Oxford, UK, 1977.

[22] J. S. Jun, "An empirical study of consumer behavior in the housing market-application of correspondence analysis and optimal scale analysis," China Soft Science, vol. 20, no. 7, pp. 153-157, 2005, in Chinese.

[23] W. S. Fen, "Application of multivariate statistical method in housing consumption analysis of urban residents in tianjin," Journal of Tianjin Polytechnic University, vol. 26, no. 1, pp. 81-84, 2007, in Chinese.

[24] W. Liu, X. Yan, and C. Xiaoshu, "Housing type differentiation and its influencing factors of urban residents in China during the transition period-analysis based on CGSS," Acta Geographica Sinica, vol. 65, no. 8, pp. 949-960, 2010, in Chinese.

[25] B. Qian, Research on Residents' Housing Type Preference Based on Correspondence Analysis, China Renmin University Press, Beijing, China, 2006, in Chinese.

[26] A. S. Jayasekare, S. Herath, R. Wickramasuriya, and P. Perez, "The price of a view: estimating the impact of view on house prices," Pacific Rim Property Research Journal, vol. 25, no. 2, pp. 141-158, 2019.

[27] K.-H. Kim, "Housing finance and urban infrastructure finance," Urban Studies, vol. 34, no. 10, pp. 1597-1620, 1997.

[28] M. M. Sweeney, "Second-tier cities: the right size at the right cost," Business Facilites: The Location Advisor, vol. 2, pp. 1-5, 2004.

[29] W. Feng, "Housing improvement and distribution in urban China: initial evidence from China's 2000 census," China Review, vol. 3, no. 2, pp. 121-143, 2003.

[30] Z. Liu, Y. Wang, and R. Tao, "Social capital and migrant housing experiences in urban China: a structural equation modeling analysis," Housing Studies, vol. 28, no. 8, pp. 1155-1174, 2013.

[31] Y. P. Wang and A. Murie, "Commercial housing development in urban China," Urban Studies, vol. 36, no. 9, pp. 1475-1494, 1999.

[32] Y. Wang, L. Zhao, L. Sobkowiak, X. Guan, and S. Wang, "Impact of urban landscape and environmental externalities on spatial differentiation of housing prices in Yangzhou City," Journal of Geographical Sciences, vol. 25, no. 9, pp. 1122-1136, 2015.

[33] Y. P. Wang, L. Shao, A. Murie, and J. Cheng, "The maturation of the neo-liberal housing market in urban China," Housing Studies, vol. 27, no. 3, pp. 343-359, 2012.

[34] L. K. Jun, "Multiple correspondence analysis and its application in job satisfaction research," Chinese Journal of Health Statistics, vol. 24, no. 2, pp. 19-21, 2007, in Chinese.

[35] M. Pritchard and T. Wilson, "Building corporate reputation through consumer responses to green new products," Journal of Brand Management, vol. 25, no. 1, pp. 38-52, 2018. 
[36] T. Chaudhry, "Estimating residential electricity demand responses in Pakistan's Punjab," The Lahore Journal of Economics, vol. 15, pp. 107-138, 2010.

[37] M. J. Greenacre, Correspondence Analysis, Academic Press, London, UK, 1984.

[38] M. Greenacre, Correspondence Analysis in Practice, Chapman and Hall/CRC, Boca Raton, FL, USA, 2017.

[39] H. Abdi and D. Valentin, "Multiple correspondence analysis," Encyclopedia of Measurement and Statistics, vol. 2, pp. 651666, 2007.

[40] M. Greenacre and J. Blasius, Multiple Correspondence Analysis and Related Methods, Chapman and Hall/CRC, Boca Raton, FL, USA, 2006.

[41] C. Ter Braak, "Partial Canonical Correspondence Analysis, Classification and Related Methods of Data Analysis," in Proceedings of the First Conference of the International Federation of Classification Societies (IFCS), pp. 551-558, Technical University of Aachen, Amsterdam, Netherlands, June 1988. 